\title{
Liter Per Liter
}

National Cancer Institute

\section{Source}

National Cancer Institute. Liter Per Liter. NCI Thesaurus. Code C105495.

A measure of volume concentration expressed as the number of liters of a dissolved substance per liter of solution. 